\title{
Exploring Discourse Patterns in Literature Circles
}

\author{
Ho Lai Ying \\ SMJK Nan Hwa, Sitiawan, Perak \\ Nor Azmi Mostafa \\ Faculty of Languages and Communication \\ Sultan Idris Education University \\ Email: janicehly78@gmail.com
}

\begin{abstract}
This study explores the discourse patterns produced by a group of ESL students and the roles played by the group discussion leaders in literature circles that effectively enhance their comprehension of the stories in graphic and non-graphic novels. Six ESL students were selected in this study and seven literature circles were conducted to gather data to address the research questions. Data were gathered from direct observation, interviews and transcripts of literature circles. The data obtained from the transcripts of literature circles showed that the students used different comprehension strategies during discussions such as questioning, evaluating, using prior knowledge, interpreting and summarising that effectively enhance their understanding of the texts. Turn-taking in discussions also showed that students with better language proficiency in English language dominated the discussions and could comprehend the stories more effectively. Data collected from the transcripts of the students' participation in literature circles and direct observation showed that the group discussion leader played an important role in assisting the group members to understand the graphic and non-graphic novels by paraphrasing the questions asked, initiating the conversation and motivating quiet group members to give personal responses and opinions during the discussions. Discourse patterns produced by the students and the group discussion leaders' roles in literature circles were analysed as to determine whether literature circles assisted the students in comprehending the graphic and non-graphic novels. The findings help teachers to improve literature circles as they know the important aspects in literature circles that should be emphasised to enhance students' comprehension.
\end{abstract}

Keywords: literature circles, discourse patterns, comprehension, graphic and non-graphic novels

\section{INTRODUCTION}

Literature circles have gained much consideration in researches for the past decades (Scott, 1994; Kim, 2004; Clarke, 2007). Implementing literature circles in the classroom as a teaching approach helps to create a collaborative environment that supports students' active participation to develop in reading (Mohamed Elhess \& Egbert, 2015). Daniels (1994) defines literature circles as small and temporary discussion groups which have been chosen to read the same story, poem, article, or 
book. Daniels adds that while reading each group determines the portion of the text either inside or outside of the class, prepares to take specific responsibilities in the upcoming discussion and comes to the group with the notes needed to perform the job. In literature circles, the members have regular meetings with discussion roles rotating each session. They need to finish reading the book, plan a way to share highlights of their reading with the wider community, trade members with other finishing groups, select more reading and move into a new cycle (Daniels, 1994).

Many researchers believed that the literature circle is a valuable method in the classroom (Clarke, 2007). Furr (2003) had conducted a research on literature circles in a group of Japanese EFL learners and found that the students were able to discuss the issues in English and solve the problem in collaboration with their peers which they could not deal with it on their own. Another study by Kummert (2014) on a group of English language learners of different language abilities. He concluded that literature circles promoted growth in numerous academic competencies and social outcomes that the students can practise such as cooperative learning, positive interdependence, group accountability and group processing. Therefore, this study aims to explore the discourse patterns produced by a group of English second language learners and how the roles of the group discussion leaders in literature circles assisted learners to comprehend the stories in graphic and non-graphic novels.

\section{LITERATURE REVIEW}

To accomplish text comprehension, readers make connections between the texts they read with their past knowledge and experiences (Brown \& Dewitz, 2014). Background information helps readers to understand the written material that they are expected to read as well as enable them to choose appropriate schemata to apply when reading. Ketch (2005) claims that a good reader makes connection in order to gain comprehension. This includes the connection to the text, the world, the reader's background knowledge and experiences so that the reader will be able to feel the characters, understand the story and make connection with similar experiences. In this study, the students used their background knowledge to comprehend the story The Kite Runner. The students related the issues in the story such as friendship betrayal, bullying, wars, gender and status discrimination in society with their previous knowledge and experiences. By making a connection between the text and background knowledge and experiences, the students were able to make different and unique interpretations when they were discussing the story.

Apart from that, text comprehension also depends on students' decoding skills and they develop these skills to reach adequate level of accuracy which underlies successful comprehension (Kintsch \& Kintsch, 2005). McLaughlin (2012) states that good readers monitor their understanding, discuss meaning and use different strategies such as rereading, changing of reading pace, using contextual clues and cross-checking cueing system to achieve comprehension. Brown and Dewitz (2014) claim that a good reader implements several strategies to construct meaning. In this study, the students employed several comprehension strategies when they engaged in literature circles. The strategies were questioning, evaluating, predicting and summarising. All these 
comprehension strategies assisted the students in constructing meaning and understanding the story.

In this study, text comprehension was achieved when the students engaged in literature circles. The students used their background knowledge and comprehension strategies to comprehend the stories in graphic and non-graphic novels. In the context of the present study, the graphic and non-graphic novels of the story The Kite Runner were chosen to be the reading materials used in literature circles. To help the students to understand the different setting and cultural background displayed in the story, the graphic novel of the story, The Kite Runner was utilised at the beginning of the literature circles. Cook (2017) points out that the images in graphic novels help students to decode meaning for comprehension. Literature circles provide opportunities for the students to enhance their comprehension of the story through implementing comprehension strategies and sharing of personal responses during literature circles.

\section{RESEARCH QUESTIONS}

To investigate the use of literature circles in assisting students' comprehension, the following research questions were developed:

a) What are the discourse patterns produced by the students during literature circles that effectively enhance their comprehension of the stories in graphic and nongraphic novels?

b) What are the roles played by the group discussion leaders in literature circles that effectively assisted the group members in comprehending the stories in graphic and non-graphic novels?

\section{METHODOLOGY}

In this study, the case study method was implemented. Yin (2009) defines case study as an empirical inquiry that investigates a contemporary phenomenon in depth and within its real-life context and this especially happens when the boundaries between phenomenon and context are not clear evident. Through case study method, the researcher was able to understand in-depth descriptions of the students' involvement in literature circles. Case study method allowed the researcher to gather data about the discourse patterns developed by the students that enhanced their comprehension of the story. The participants engaged in seven literature circles and data were gathered through direct observation, interviews and transcripts of literature circles. Direct observation was carried out in each literature circle and the researcher observed the students when they engaged in the discussions. Individual interviews were conducted after each literature circle and group interviews were carried out after all literature circles were completed. The literature circles were audiotaped and transcribed verbatim. The researcher then analysed the transcripts of literature circles to identify emerging themes or patterns. This study was carried out in a Chinese medium school in Sitiawan, Perak. Purposive sampling of six upper secondary form four students were selected to be the participants. The students were average learners based on the PT3 examination and they obtained A for English language. When the study was carried out, 
the participants were referred to as Janez, Li Sheng, Jin Sheng, Pei Li, Le Ying and Jia Jin (these are not their real names).

\section{RESULTS AND DISCUSSION}

\section{Research Question 1}

What are the discourse patterns produced by the students during literature circles that effectively enhance their comprehension of the stories in graphic and non-graphic novels?

To answer research question one, data were collected through direct observation, interviews and transcripts of literature circles. The discourse patterns produced by the students were shown when the students employed comprehension strategies in literature circles. The transcripts of literature circles were analysed to identify the comprehension strategies used by the students when they engaged in literature circles. The list of comprehension strategies by Clark (2009) was used to guide the analysis. The comprehension strategies used in Clark's study were comparing or contrasting, contextualising, stating a confusion, questioning, searching for meaning, using prior knowledge, evaluating, interpreting, inserting oneself in the text, noting author's craft, engaging in retrospection and summarising.

Some of the comprehension strategies listed by Clark (2009) were not used in the data analysis as they were not employed by the students in literature circles. The comprehension strategies that were not used by the students in literature circles were comparing or contrasting, contextualising, stating a confusion, searching for meaning, noting author's craft, and engaging in retrospection. In analysing the data, comprehension strategies were identified in the transcripts and given codes such as $(\mathrm{Q})$ for questioning, (E) for evaluating and (I) for interpreting. The frequency of each comprehension strategy was calculated to determine the most frequent reading comprehension strategy used by the students in literature circles. To identify the discourse patterns produced by the students in literature circles, data were analysed by practising critical discourse analysis (CDA). Wodak and Meyer (2009) state that the fundamental principle in critical discourse analysis is to acknowledge that language is a social practice and the context of language use is crucial. Helgeson (2017) claims that literature circles allow high levels of interaction among students and provide opportunity for students to discuss with their peers about literature.

Thus, to implement critical analysis of the discourse, the languages used by the students in literature circles need to be examined (Clarke, 2007). In exploring the discourse patterns produced by the students, turn-taking system in discussion was analysed. The frequencies of turn-taking in the students' discussions were counted to determine whether equal turn-taking system occurred in literature circles. The transcripts of literature circles were also analysed to examine the roles played by the group discussion leaders in assisting the group members' comprehension of the text. The transcripts were coded with codes such as giving orders, approving, disagreeing, using reinforcement, giving responses and interrupting. After coding was completed, the themes or patterns which emerged in the transcripts were identified. 


\section{Comprehension Strategies}

The data obtained from the transcripts of literature circles revealed that the students employed different comprehension strategies when they engaged in literature circles to enhance their comprehension of the story. The students' comprehension strategies and examples taken from the literature circles are shown in Table 1. The frequency of each comprehension strategy used in literature circles was counted and the results are tabulated (see Table 2).

\section{Table 1: Comprehension Strategies Found in the Literature Circles}

\begin{tabular}{|c|c|}
\hline Strategy & Examples \\
\hline $\begin{array}{l}\text { 1. Questioning } \\
\text { Posing a Question }\end{array}$ & $\begin{array}{l}\text { a) Why do you think that the author would write this kind of book? About the situation } \\
\text { in Afghanistan? } \\
\text { b) Pei Li, let me ask you another question? If you have experienced the situation like } \\
\text { Hassan and Amir, friendship, how do you feel? } \\
\text { c) What you guys think the reasons Shorab want to stop Assef? } \\
\text { d) What do think about 'for you a thousand times over' mean? }\end{array}$ \\
\hline $\begin{array}{l}\text { 4. Interpreting } \\
\text { Taking information } \\
\text { from the story and } \\
\text { assigning its } \\
\text { meaning. }\end{array}$ & $\begin{array}{l}\text { a) I think he thinks that he treats him like his best friend so he is willing to do } \\
\text { anything. No matter what it costs, he would do that for him. } \\
\text { b) I think that if Baba told Amir about it, later Amir may hate him for the rest of his } \\
\text { life. } \\
\text { c) I think he just wants him to keep a distance from him. } \\
\text { d) I feel that Hassan previous life is taken care by Baba and his family. He has home } \\
\text { to stay so he wants to repay his kindness. }\end{array}$ \\
\hline $\begin{array}{l}\text { 5. Inserting oneself } \\
\text { in the text } \\
\text { Students place } \\
\text { themselves in the } \\
\text { story. }\end{array}$ & $\begin{array}{l}\text { a) If I am Shorab, I will not do as what Janez said...run away. If I run away, I don't } \\
\text { know where to run and what to do. } \\
\text { b) In my opinion, if I am the parent, I will not adopt children because when I teach } \\
\text { them, they will say that I am not their real parent. Why do I need to listen to you? } \\
\text { c) If I were Baba, I will think this way even I was happy in Peshawar but here Amir } \\
\text { cannot have a better environment for study, cannot have a better life,cannot get a } \\
\text { better education. But it is different in America, even if I hate the place, I will suffer } \\
\text { living there but I can get a better life for Amir. }\end{array}$ \\
\hline $\begin{array}{l}\text { 6. Summarising } \\
\text { Reviewing two or } \\
\text { more events or } \\
\text { ideas. }\end{array}$ & $\begin{array}{l}\text { a) This story in Chapter } 1 \text { to } 9 \text { is actually the flashback. Amir, the main character, now } \\
\text { he lives in California recall the incident and his best friend, Hassan, stays in Kabul, } \\
\text { and Hassan is an excellent kite runner and his father, Ali was Baba's servant. After } \\
\text { the children won the kite flying tournament and the Assef, with the our protagonist } \\
\text { character in this novel and he met Hassan and he seek for the revenge because earlier } \\
\text { we know that Hassan shot him with a slingshot. } \\
\text { b) I just give a brief summary. As we know that, Amir and Baba left Kabul and even } \\
\text { Afghanistan. Afghanistan is declared as a war zone and Amir deepen his writing } \\
\text { skills and become a writer as mentioned in the book and produce a book. After that, } \\
\text { we know that Baba is suffered from cancer and Amir marry Soraya before Baba } \\
\text { dead and finally Amir went to Pakistan after he received a call from Amir Khan in } \\
\text { 2001. Rahim Khan said there is a way to be good again. }\end{array}$ \\
\hline
\end{tabular}

To ensure the reliability of the data obtained in Table 1 , the researcher requested help from two senior teachers with 20 years teaching experience in secondary schools as raters to validate the data collected. The senior teachers were asked to identify the comprehension strategies for the responses mentioned by the students in literature circles. The inter-rater agreement was calculated based on Kappa Statistic. The result 
of the calculation shows fair agreement. Appendix 1 shows the responses from the raters. Appendix 2 displays the results of the inter-rater agreement. Appendix 3 shows the calculation of inter-rater reliability based on Kappa Statistic and Appendix 4 shows the interpretation of Kappa Statistic.

Table 2: Frequency of Comprehension Strategies in Literature Circles

\begin{tabular}{|c|c|c|c|c|c|c|c|}
\hline \multirow{2}{*}{ Strategy } & \multicolumn{7}{|c|}{$\begin{array}{l}\text { Frequency and } \\
\text { Percentage }(\%)\end{array}$} \\
\hline & $\begin{array}{c}\mathrm{LC} \\
1\end{array}$ & $\begin{array}{c}\mathrm{LC} \\
2\end{array}$ & $\begin{array}{c}\mathrm{LC} \\
3\end{array}$ & $\begin{array}{c}\mathrm{LC} \\
4\end{array}$ & $\begin{array}{c}\mathrm{LC} \\
5\end{array}$ & $\begin{array}{c}\mathrm{LC} \\
6\end{array}$ & $\begin{array}{c}\mathrm{LC} \\
7\end{array}$ \\
\hline Questioning & $\begin{array}{c}9 \\
(27.3)\end{array}$ & $\begin{array}{c}14 \\
(29.8)\end{array}$ & $\begin{array}{c}9 \\
(45.0)\end{array}$ & $\begin{array}{c}14 \\
(20.9)\end{array}$ & $\begin{array}{c}7 \\
(19.4)\end{array}$ & $\begin{array}{c}17 \\
(26.6)\end{array}$ & $\begin{array}{c}11 \\
(19.6)\end{array}$ \\
\hline Evaluating & $\begin{array}{c}14 \\
(42.4)\end{array}$ & $\begin{array}{c}16 \\
(34.1)\end{array}$ & $\begin{array}{c}6 \\
(30.0)\end{array}$ & $\begin{array}{c}25 \\
(37.3)\end{array}$ & $\begin{array}{c}19 \\
(52.8)\end{array}$ & $\begin{array}{c}35 \\
(54.6)\end{array}$ & $\begin{array}{c}34 \\
(60.7)\end{array}$ \\
\hline $\begin{array}{l}\text { Using prior } \\
\text { knowledge }\end{array}$ & $\begin{array}{c}2 \\
(6.1)\end{array}$ & $\begin{array}{c}4 \\
(8.5)\end{array}$ & $\begin{array}{c}0 \\
(0)\end{array}$ & $\begin{array}{c}6 \\
(8.9)\end{array}$ & $\begin{array}{c}0 \\
(0)\end{array}$ & $\begin{array}{c}2 \\
(3.1)\end{array}$ & $\begin{array}{c}1 \\
(1.8)\end{array}$ \\
\hline Interpreting & $\begin{array}{c}4 \\
(12.1)\end{array}$ & $\begin{array}{c}5 \\
(10.6)\end{array}$ & $\begin{array}{c}3 \\
(15.0)\end{array}$ & $\begin{array}{c}17 \\
(25.4)\end{array}$ & $\begin{array}{c}8 \\
(22.2)\end{array}$ & $\begin{array}{c}4 \\
(6.3)\end{array}$ & $\begin{array}{c}2 \\
(3.6)\end{array}$ \\
\hline $\begin{array}{l}\text { Inserting } \\
\text { oneself in } \\
\text { the text }\end{array}$ & $\begin{array}{c}1 \\
(3.0)\end{array}$ & $\begin{array}{c}5 \\
(10.6)\end{array}$ & $\begin{array}{c}1 \\
(5.0)\end{array}$ & $\begin{array}{c}4 \\
(6.0)\end{array}$ & $\begin{array}{c}0 \\
(0)\end{array}$ & $\begin{array}{c}4 \\
(6.3)\end{array}$ & $\begin{array}{c}6 \\
(10.7)\end{array}$ \\
\hline Summarising & $\begin{array}{c}3 \\
(9.1)\end{array}$ & $\begin{array}{c}3 \\
(6.4)\end{array}$ & $\begin{array}{c}1 \\
(5.0)\end{array}$ & $\begin{array}{c}1 \\
(1.5)\end{array}$ & $\begin{array}{c}2 \\
(5.6)\end{array}$ & $\begin{array}{c}2 \\
(3.1)\end{array}$ & $\begin{array}{c}2 \\
(3.6)\end{array}$ \\
\hline Total & $\begin{array}{c}33 \\
(100)\end{array}$ & $\begin{array}{c}47 \\
(100)\end{array}$ & $\begin{array}{c}20 \\
(100)\end{array}$ & $\begin{array}{c}67 \\
(100)\end{array}$ & $\begin{array}{c}36 \\
(100)\end{array}$ & $\begin{array}{c}64 \\
(100)\end{array}$ & $\begin{array}{c}56 \\
(100)\end{array}$ \\
\hline
\end{tabular}

Note. $\mathrm{LC}=$ Literature Circle

The researcher also applied check-coding (Miles \& Huberman, 1994) to ensure reliability applied in the data collected in Table 1 . This involved the researcher coded the same transcripts twice at different times. Table 2 shows the frequency of the comprehension strategies implemented by the students in literature circles. The results reveal that the students used comprehension strategies such as questioning, evaluating, interpreting, using prior knowledge, inserting oneself in the text and summarising when they discussed the graphic and non-graphic novels in literature circles.

The results in Table 2 also show that evaluating the text is the most frequent strategy used by the students in seeking information and comprehending the story. The 
students shared their opinions and responses about the characters and events in the story. Clark (2009) mentioned in her study that the two easiest strategies used by the students in finding information and giving their opinions were questioning and evaluating. The second most frequent comprehension strategy used by the students in this study is questioning. Certo, Moxley, Reffitt, and Miller (2010) claim that students acquire the questioning skills for meaning-making.

In this study, the data obtained from the direct observation revealed that the group discussion leaders employed questioning strategy to get the group members contributing their responses about the topic discussed in literature circles. The group members also questioned one another if they were uncertain about the questions asked or the issue discussed in literature circles. The data in Table 2 also shows that the comprehension strategies such as inserting oneself in the text and using prior knowledge were not used frequently in literature circles. The findings in this study suggest that the students were unaware of other important comprehension strategies that could help to enhance their understanding of the story. The following excerpt 1 shows the comprehension strategies employed by the students when they talked about the issue of marriage of the main character in the story.

\section{Excerpt 1}

Janez: I would like to ask if you were Amir's father, would you allow Amir to marry a lady like Soraya?

Li Sheng: It all depends on that person. In the 70s and 80s, people are not open-minded. They are a bit old timer. If you are a person in 90 s and 80 s, maybe they will reject. But now, if you think as a young man, I mean in the $21^{\text {st }}$ century, maybe he will accept.

Janez: $\quad$ You...you would accept?

Li Sheng: I think that if she really loves me and I really love her then maybe I will.

Janez: Thank you then if you are Amir's father.

Li Sheng: $\quad$ I think I have to respect my son's decision.

Janez: Ok. Jia Jin, how about you?

Jia Jin: Don't know what to say.

Janez: Jin Sheng?

Le Ying: $\quad$ I think we all agree with what he said.

Janez: $\quad$ Ok but if I am Amir's father, I will not agree with my son because this girl is not so healthy.

Jia Jin: (Laughs)

Janez: $\quad$ Maybe...maybe if we have our child then our child grown up already. She will also be like her mother maybe lar so to prevent this happen. I will not let my son to marry her.

The comprehension strategies used by the students in Excerpt 1 were questioning, evaluating and inserting oneself in the text. The group discussion leader, Janez, questioned the group members whether they would allow the main character in the story, Amir to marry Soraya, a lady who is unable to conceive. One of the group members, Li Sheng evaluated the issues discussed by mentioning that he would accept the marriage if he was in love with Soraya. The group discussion leader then gave his own opinion and he implemented the comprehension strategy, inserting oneself in the text as the main character, Amir's father. He said that he would not allow his son, Amir to marry the lady as she is unhealthy and her health condition would affect her future 
generation. There was another support in the data that showed the students employed different comprehension strategies in a literature circle to enhance their comprehension of the text. In Excerpt 2, the students discussed about a statement mentioned by the main character, Amir on his wedding day.

\section{Excerpt 2}

Pei Li: $\quad$ Amir mentioned when he saw their face on the mirror. I see the rest of my life. What do you guys think about this statement?

Le Ying: $\quad$ For me it is not just a point of view or just a sentence. I think that when Amir said that I see the rest of my life it means a promise about to Soraya that he loves her, cares for her and willing to use his whole life to cherish her. To protect her and be a good husband. It is about to her that he would take care of her and would never betray her or left her alone. Yes that.

Pei Li: Jin Sheng, what do you think about Amir said I see the rest of my life in the mirror?

Jin Sheng: I think Amir said this sentence because he was wondering about his future of his life. He looked through the mirror and see his wife and he is wondering they have a kid. Just like the picture beside there. Three people were standing there.

Pei Li: $\quad$ Ok. Let us discuss about this matter. I think that it is a picture of guests because if he said I see the rest of my life at the end of the story. He mentioned that at the end. Maybe at the beginning it is a picture of guests watching them. Like witness the ceremony. What do you guys think about it?

Le Ying: I agree with Pei Li because that you can see from the picture. The first picture, from my opinion I think is Baba and then the second picture is them. The third picture is another something not related. I disagree with your opinion that it show their future. From my point of view, I think that they are just guests only.
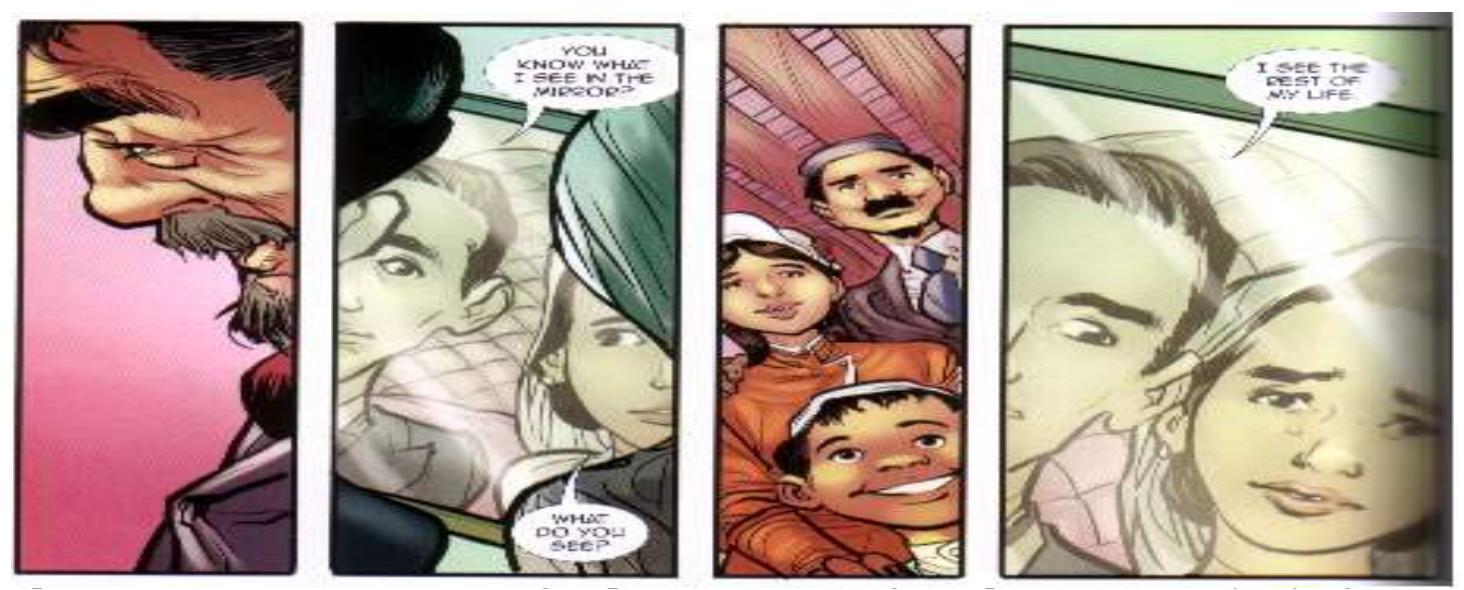

was Amir's promise to Soraya that he would love and care for her. In order to get other group members to give their responses as well, Pei Li questioned a quiet member, Jin Sheng for his opinion. Jin Sheng commented that the main character, Amir wondered about his future and he saw his future with his wife and a kid. He then added that the third picture showed Amir's future with his family. A different interpretation was given by Jin Sheng.

The discussion continued when the group discussion leader, Pei Li also voiced her opinion during the literature circle. She had a different interpretation as she mentioned that the third picture showed the guests who attended Amir's wedding day. 
Her response was supported by Le Ying as she also agreed with her opinion and she added that the picture did not show Amir's future with his wife. The data obtained from the direct observation revealed that the students had an active discussion in the literature circle as they made different interpretations of the pictures in the graphic novel and supported their argument with explanation. Jennings, Rule and Zanden (2014) state that students' interest in reading is increased and their learning with peers through discussion is broadened when graphic novels are used in literature circles.

Fairclough (2015) states that discourse is not just language and it involves meaning-making and the resources that are used in it. In this study, the students were given conversation starter card 1 to assist them in constructing proper sentences during literature circles. For the group discussion leaders, guidelines card 2 and 3 were given to guide them in constructing appropriate questions to ask the group members. Direct observation was conducted during the discussions and the data revealed that the students were able to communicate well and respond to the questions asked by the group discussion leader using the conversation starter cards even though some minor mistakes were made in their sentences. The group discussion leader also constructed questions using the guidelines cards to get responses from the group members.

Excerpt 3 and 4 display some of the ideas expressed by the students in literature circles using the conversation starter card 1. Except 5 and 6 show the questions asked by the group discussion leader using the guidelines cards.

\section{Excerpt 3}

Le Ying: I disagree with your view of thinking that it reflect our life. I think that it doesn't reflect our life because our life we have never experience war before. We never face any of the cruelty in the story. So I disagree with you. It talks about Afghanistan and only the children in the third world experience such matter. So, I disagree with your view that the story reflecting our life.

\section{Excerpt 4}

Pei Li: $\quad$ I totally agree with Janez's opinion. Nowadays, people just stand for themselves. They are selfish without care for others. How about your guy opinion?

\section{Excerpt 5}

Janez: Jia Jin, why do you think that Hassan would say to Amir in Chapter One that for you a thousand times over?

\section{Excerpt 6}

Li Sheng: My next question is why Hassan is willing to sacrifice his life just to protect the house from the Taliban? 


\section{Turn-Taking}

Turn-taking in literature circles was analysed in this study. The data were collected from the transcripts of the students' discussions in literature circles and direct observation. The results are tabulated in Table 3. Maroni, Gnisci, and Pontecorvo (2008) state that turn-taking in conversation is an important issue in the classroom and it is an essential component in the teaching and learning process. Fairclough (2001) mentions that when all members share equal power in conversation, turn-taking rights will be equally shared out as well. Turn-taking system in conversation was analysed in this study as to determine whether equal turn-taking takes place in literature circles for each student in this study to contribute their responses so that they can understand the story better. The data in the direct observation showed that there was dominance of girls in the literature circles. Even though, there were four boys in this study compared to only two girls, the boys' voices were not equally heard in the discussions.

Clarke (2007) mentioned in his study that small-group discussions dominated by boys is not a new discovery and the domination has become a common sense. In this study, the evidence found in the direct observation revealed that the domination of boys did not occur in this study and the opposite gender, the girls dominated the discussions. In the interviews conducted with the students, the data showed that the girls, Pei Li and Le Ying were really interested in reading the graphic and non-graphic novels and gathering in literature circles were the opportunities for them to share everything they knew about the story. In an unstructured interview with the students at the beginning of this study, Le Ying informed the researcher that she finished reading the non-graphic novel in two days. The data from the direct observation revealed that Le Ying and Pei Li participated actively in literature circles by asking a lot of questions, making predictions and expressing their personal responses confidently during the discussions.

The results in Table 3 show that both girls, Le Ying and Pei Li dominated the literature circles. Mahdavi and Tensfeldt (2013) state that participating actively in making predictions, asking questions about the text and relating the reading text to what had been understood are essential elements in understanding what they are reading. Clark (2009) mentioned in her study that students must initially share their questions and understand the text while reading individually, listen and think of the responses, question others during the discussions and work with group members in order to develop a better understanding of the text. The data gained from the direct observation also showed that both girls, Le Ying and Pei Li were active group discussion leaders. They asked the group members questions to get their responses and encourage the quiet members to voice their opinions during the discussions.

Table 3: Frequency of Turn-Taking in Literature Circles

\begin{tabular}{|lcccccccc|c|}
\hline $\begin{array}{l}\text { Student/ } \\
\text { Literature } \\
\text { Circle }\end{array}$ & LC1 & LC2 & LC3 & LC4 & LC5 & LC6 & LC7 & Total \\
\hline Janez & $\begin{array}{c}20 \\
(\mathrm{GDL})\end{array}$ & $\begin{array}{c}29 \\
(\mathrm{GDL})\end{array}$ & 4 & 24 & 10 & 17 & 14 & 118 \\
\hline
\end{tabular}




\begin{tabular}{|lcccccccc|}
\hline Li Sheng & 5 & 18 & $\begin{array}{c}15 \\
(\mathrm{GDL})\end{array}$ & $\begin{array}{c}35 \\
(\mathrm{GDL})\end{array}$ & 15 & 14 & 10 & 112 \\
\hline Le Ying & 16 & 30 & 7 & 55 & $\begin{array}{c}30 \\
(\mathrm{GDL})\end{array}$ & 40 & 31 & 209 \\
\hline Pei Li & 9 & 16 & 3 & 45 & 20 & $\begin{array}{c}54 \\
(\mathrm{GDL})\end{array}$ & 34 & 181 \\
\hline Jin Sheng & 5 & 4 & 3 & 2 & 5 & 8 & 6 & 33 \\
\hline $\begin{array}{l}\text { Jia Jin } \\
\begin{array}{l}\text { Note. GDL = Group Discussion Leader } \\
\text { LC = Literature Circle }\end{array}\end{array}$ & 11 & 17 & 2 & 17 & 6 & 12 & $\begin{array}{c}23 \\
(\mathrm{GDL})\end{array}$ & 88 \\
\hline
\end{tabular}

\section{Research Question 2}

What are the roles played by the group discussion leaders in literature circles that effectively assisted the group members in comprehending the stories in graphic and non-graphic novels?

To conduct a successful literature circle, the group discussion leader plays an important role. In this study, the roles of group discussion leaders were examined whether they helped the group members in comprehending the graphic and non-graphic novels. Data collected from the transcripts of the students' participation in literature circles and direct observation showed that the group discussion leaders initiated the discussions by asking the group members to give their responses. This effort encouraged the group members to respond to the questions asked and they would not just sit quietly without giving any responses. By encouraging the group members to express their opinions, this actually made them think about the story and gave them the opportunities to tell the group members their personal responses. This assisted the group members in comprehending the texts.

Maloch and Beutel (2009) highlight that student's initiations provide awareness about their interest and encourage meaning-making as they are able to engage with the text. Apart from that, the data obtained from the transcripts of the literature circles revealed that the group discussion leaders paraphrased the questions when the group members were unable to give their responses. This helped the group members to understand the questions asked and they were able to contribute their personal responses. Besides, the evidence gained from the direct observation showed that the group discussion leaders motivated the group members by giving them positive comments after listening to their responses or they had performed their tasks on the role sheets successfully. The examples of the roles performed by the group discussion leaders are displayed in Table 4. 
Table 4: Roles of the Group Discussion Leaders in Literature Circles

\begin{tabular}{|c|c|}
\hline $\begin{array}{l}\text { Role of the group discussion } \\
\text { leader }\end{array}$ & Discourse Patterns Used \\
\hline 1. Initiating conversation & $\begin{array}{l}\text { a) Do you have any opinion? } \\
\text { b) Do all of you have anything to say about this matter? } \\
\text { c) Can you list out some vocabulary? } \\
\text { d) How about the rest? } \\
\text { e) What do you think about it, Pei Li? } \\
\text { f) Is there anything that we can discuss? } \\
\text { g) Any interesting part that we can discuss? } \\
\text { h) Anything else to discuss? } \\
\text { i) What do you guys think about it? } \\
\text { j) Do you guys have anything to add on? } \\
\text { k) I feel that there is something that worth all of us to discuss } \\
\text { l) What is your opinion, Jin Sheng? } \\
\text { m) Is there any other opinion? }\end{array}$ \\
\hline $\begin{array}{l}\text { 2. Paraphrasing the } \\
\text { questions }\end{array}$ & $\begin{array}{l}\text { a) Which part in the graphic novel that you find interesting? } \\
\text { Any suggestion? In other ways what do you feel when you } \\
\text { see example from page } 41 \text { to } 45 \text {. What do you feel when } \\
\text { you see the pictures? } \\
\text { b) Tell us your feeling after reading the graphic novel or you } \\
\text { all feel that any interesting story in the graphic novel that } \\
\text { you want to tell us your opinion. } \\
\text { c) Should not say how Baba feel about it but should say what } \\
\text { we think about this matter. }\end{array}$ \\
\hline
\end{tabular}

Table 5: Roles of the Group Discussion Leaders in Literature Circles (continued)

\begin{tabular}{|l|ll|}
\hline $\begin{array}{c}\text { Role of the group discussion } \\
\text { leader }\end{array}$ & \multicolumn{1}{c|}{ Discourse Patterns Used } \\
\hline $\begin{array}{l}\text { 3. Motivating group } \\
\text { members }\end{array}$ & a) & Keep going \\
& b) & Responsibility. Correct...correct. \\
c) & Very relevant \\
d) & Thanks for you guys opinions and explanation of the \\
& thoughts. \\
& e) & Jin Sheng, I haven't heard your opinion. Could you \\
& flease say something about it? & Le Ying's opinion is correct. \\
& g) & Thank you for your share. \\
& h) & Thank you for your brief summary. \\
& i) & I am sure that we have learnt so much words today. \\
& j) & Don't be stressed ya. Just tell your opinion. \\
k) & Pei Li is right. \\
& l) & Jin Sheng, you want to speak? \\
& \\
\hline
\end{tabular}




\section{CONCLUSION}

Engaging students in a more authentic student-led discussion is a challenging task for teachers in the classroom (Certo et al., 2010). In literature circles, students are actively involved in their learning as they contribute to the group discussion and think critically (McCall, 2010). In this study, the data collected to answer the research questions show different discourse patterns portrayed by the students when they involve in literature circles. The discourse patterns that effectively enhanced their comprehension of the graphic and non-graphic novel are the comprehension strategies employed by the students in literature circles and turn-taking during the discussions. The findings of this study reveal that questioning and evaluating are the most frequent comprehension strategies used by students when they gather in literature circles. It is recommended that teachers encourage students to question the group members during literature circles so that they can express their personal responses, listen to their peer's ideas and gain understanding of the text. Students can also learn other comprehension strategies such as thinking aloud, making connections, visualising, questioning the author and reflecting which can be applied before, during and after literature circles. Besides, unequal turn-taking happens in literature circles. The findings indicate that students with better language proficiency and interest in reading dominate literature circles. To overcome unequal turn-taking, it is suggested that students should fully utilise the conversation starter card 1 and guidelines card 2 and 3 in literature circles. This will encourage the quiet members to contribute their opinion during the discussions. The group discussion leader plays an important role in a literature circle as he initiates conversation, paraphrases questions and motivates group members during the discussion. These roles help the group members to comprehend the story in literature circles. Lastly, it is hoped that by engaging students in literature circles, their comprehension of the texts is improved and this helps them to acquire better communication skills for the $21^{\text {st }}$ century workplace.

\section{REFERENCES}

Brown, R., \& Dewitz, P. (2014). Building comprehension in every classroom: Instruction with literature, informational texts, and basal programs. New York: The Guilford Press.

Certo, J., Moxley, K., Reffitt, K., \& Miller, J. A. (2010). I learned how to talk about a book: Children's perceptions of literature circles across grade and ability levels. Literacy Research and Instruction, 49, 243-263. doi:10.1080/19388070902947352

Clark, K. F. (2009). The nature and influence of comprehension strategy use during peer-led literature discussions: An analysis of intermediate grade students' practice. Literacy Research and Instruction, 48, 95-119. doi:10.1080/19388070802226295

Clarke, L. W. (2007). Discussing Shiloh: A conversation beyond the book. Journal of Adolescent \& Adult Literacy, 51(2), 112-122. doi:10.1598/JAAL.51.2.3

Cook, M. P. (2017). Now I "see": The impact of graphic novels on reading comprehension in high school English classrooms. Literacy Research and Instruction, 56(1), 21-53. doi:10.1080/19388071.2016.1244869

Daniels, H. (1994). Literature circles: Voice and choice in the student-centered classroom. York, Maine: Stenhouse Publishers.

Fairclough, N. (2001). Language and power (2nd ed.). New York: Longman.

Fairclough, N. (2015). Language and power (3rd ed.). New York: Routledge. 
Furr, M. (2003). Literature circles for the EFL classroom. Proceedings of the 2003 TESOL Arabia Conference.

Retrieved from http://www.eflliteraturecircles.com/litcirclesforEFL.pdf

Helgeson, J. (2017). Differentiating through literature circles. Kappa Delta Pi Record, 53(1), 41-44. doi: 10.1080/00228958.2016.126481

Jennings, K. A., Rule, A. C., \& Zanden, S. M. V. (2014). Fifth graders' enjoyment, interest, and comprehension of graphic novels compared to heavily-illustrated and traditional novels. International Electronic Journal of Elementary Education, 6(2), 257-274. Retrieved from http://www.iejee.com/6_2_2014/IEJEE_6_2_Jennings_Rule_Zanden.pdf

Ketch, A. (2005). Conversation: The comprehension connection. The Reading Teacher, 59(1), 8-13. doi:10.1598/RT.59.1.2

Kim, M. (2004). Literature discussions in adult L2 learning. Language and Education, 18(2), 145-165. doi: 10.1080/09500780408666872

Kintsch, W., \& Kintsch, E. (2005). Comprehension. In S. G. Paris \& S. A. Stahl (Eds.), Children's reading comprehension and assessment (pp.71-92). London: Lawrence Erlbaum Associates, Publishers.

Kummert, N. (2014). Supporting English language learners with literature circles. Curriculum In Context, 6, 22-24.

Retrieved from http://wsascd.org/downloads/curriculum_in_context/Spring_2014_Articles

Mahdavi, J. N., \& Tensfeldt, L. (2013). Untangling reading comprehension strategy instruction: Assisting struggling readers in the primary grades. Preventing School Failure, 57(2), 7792. doi: 10.1080/1045988X.2012.668576

Maloch, B., \& Beutel, D. D. (2009). "Big loud voice. You have important things to say": The nature of students initiations during one teacher's interactive read-alouds. Journal of Classroom Interaction, 45(2), 20-29.Retrieved from http://www.jstor.org/stable/ 23870348

Maroni, B., Gnisci, A., \& Pontecorvo, C. (2008). Turn-taking in classroom interactions: Overlapping, interruptions and pauses in primary school. European Journal of Psychology of Education, 23, 59-76. Retrieved from http://www.jstor.org/stable/23421618

McCall, A. L. (2010). Teaching powerful social studies ideas through literature circles. The Social Studies, 101(4), 152-159. doi: 10.1080/00377990903284104

McLaughlin, M. (2012). Reading comprehension: What every teacher needs to know. The Reading Teacher, 65(7), 432-440. doi: 10.1002/TRTR.01064

Mohamed Elhess., \& Egbert, J. (2015). Literature circles as support for language development. English Teaching Forum, 13-21. Retrieved from https://americanenglish.state.gov/files/ae/. source03_etf_53-3_3_elhess_egbert.pdf

Miles, M. B., \& Huberman, A. M. (1994). Qualitative data analysis (2nd ed.). Thousand Oaks, California: SAGE Publications, Inc.

Scott, J. E. (1994). Literature circles in the middle school classroom: Developing reading, responding, and responsibility. Middle School Journal, 26(2), 37-41. Retrieved from http://www.jstor.org/stable/23023959

Viera, A. J., \& Garrett, J. M. (2005). Understanding interobserver agreement: The Kappa statistic. Family Medicine, 37(5), 360-363. Retrieved from http://virtualhost.cs.columbia.edu/ julia/courses/CS6998/Interrater_agreement.Kap pa_statistic.pdf

Wodak, R., \& Meyer, M. (2009). Critical discourse analysis: History, agenda, theory, and methodology. Methods of critical discourse analysis. London: Sage Publications. Retrieved from https://www.corwin.com/sites/default/files/upmbinaries/24615_01_Wodak_Ch_01.pdf 
Yin, R. K. (2009). Case study research: Design and methods (4th ed.). Thousand Oaks, California: SAGE Publications.

Responses from the Raters

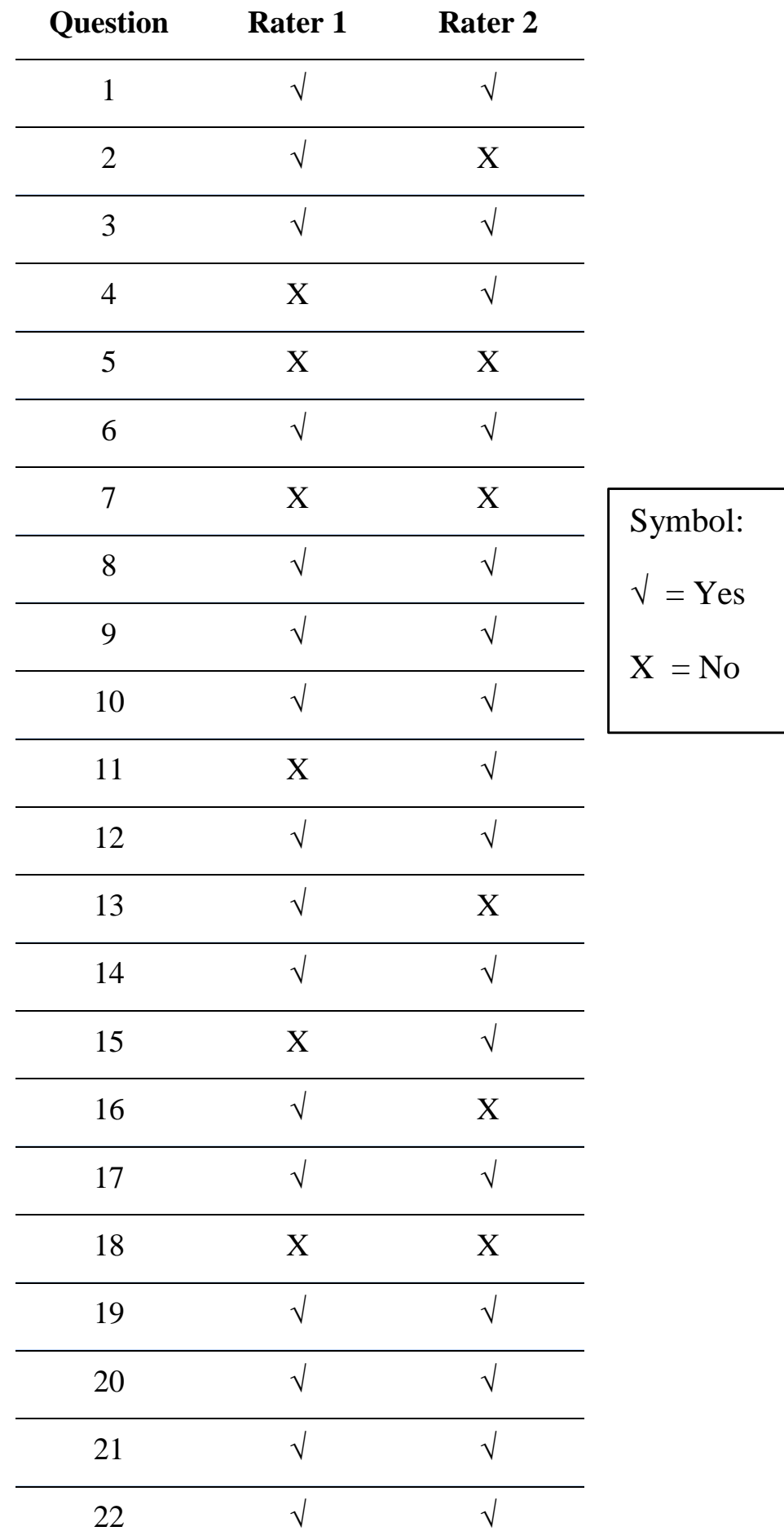

Summary of the responses:

13 questions were rated Yes by both. 
3 questions were rated No by both.

Overall, rater A said Yes to 16 questions and No to 6 questions.

Overall, rater B said Yes to 16 questions and No to 6 questions.

Results of the Inter-Rater Agreement

Appendix 2

\begin{tabular}{|c|c|c|c|}
\hline & & & Total \\
\hline Yes & 13 & 3 & 16 \\
\hline No & 3 & 3 & 6 \\
\hline Total & 16 & 6 & 22 \\
\hline
\end{tabular}

Counting Inter-Rater Agreement Based on Kappa Statistic

Appendix 3

Step 1: Calculate Po (The relative observed agreement among raters)

13 questions were rated Yes by both.

3 questions were rated No by both.

So, $\mathrm{Po}=$ number in agreement $/$ total $=(13+3) / 22=0.73$

Step 2: Find the probability that the raters would randomly both say Yes.

Rater A said Yes to 16/22 questions or $73 \%$ / 0.73 .

Rater B said Yes to 16/22 questions or $73 \%$ / 0.73.

The total probability of the raters both saying Yes randomly is $=0.73 \times 0.73=0.53$

Step 3: Calculate the probability that the raters would randomly both said No.

Rater A said No to $6 / 22$ questions or $27 \%$ or 0.27 .

Rater B said No to $6 / 22$ questions or $27 \%$ or 0.27 .

The total probability of the raters both saying No randomly is $=0.27 \times 0.27=0.07$

Step 4: Calculate Pe (The hypothetical probability of chance agreement). Add the answers from Step 2 and 3 to get the overall probability that the raters would randomly agree.

$\mathrm{Pe}=0.53+0.07=0.6$ 
Step 5: Insert the calculations into the formula and solve it.

$\mathrm{K}=\frac{\operatorname{Pr}(a)-\operatorname{Pr}(e)}{1-\operatorname{Pr}(e)}$

Kappa, $\mathrm{K}=(0.73-0.6) /(1-0.6)=0.13 / 0.4=0.325$

Kappa, $\mathrm{K}=0.325$, which indicates fair agreement.

Interpretation of Kappa Statistic

Appendix 4

\begin{tabular}{|cl|}
\hline Kappa & Agreement \\
\hline$<0$ & Less than chance agreement \\
\hline $0.01-0.20$ & Slight agreement \\
\hline $0.21-0.40$ & Fair agreement \\
\hline $0.41-0.60$ & Moderate agreement \\
\hline $0.61-0.80$ & Substantial agreement \\
\hline $0.81-0.99$ & Almost perfect agreement \\
\hline
\end{tabular}

Adopted from "Understanding Interobserver Agreement: The Kappa Statistic," by A. J. Viera and J. M. Garrett, 2005, Family Medicine, 37, p. 362.

\section{AUTHORS}

Ho Lai Ying is an English language teacher at SMJK Nan Hwa, Sitiawan, Perak. She has 17 years of experience as an educator in primary and secondary schools. She is currently pursuing her PhD in TESL at UPSI, Tanjung Malim. Her research interests include reading and teaching of literature.

Nor Azmi Mostafa is Associate Professor at the Faculty of Languages and Communication, Sultan Idris Education University, Malaysia. He possesses a Ph.D. from University of Malaya, a M.Ed. from University of Houston, Texas USA, a B.A. (Hons.) Educ. degree from University Science Malaysia and a Diploma in General Translation from the National Translation Institute Malaysia. His areas of expertise are English Language, Curriculum and Instruction, TESL Methodology, Sociolinguistics and Bilingualism. He has 30 years teaching experience in the education field. His research activities focus on English language teaching and learning and he has presented papers in national and international conferences. 